\title{
Bio-bleaching of Dyed Cotton Fabric Using a Bacterial Catalyst
}

\begin{abstract}
Anaerobically grown cells of Shewanella strain J18 143 were able to bio-bleach the color from cotton fabric that was dyed with Remazol Black B (C.I. Reactive Black 5), a common diazo reactive dye. This bio-bleaching process, involving a bacterial catalyst, offers potential benefits to the color industry as the removal of color from dyed fabric opens up the potential for fabric re-use. Growing cells removed the color with greater efficiency than that achieved using pre-grown "resting" cells. Assays of resting cells were used to determine the effect of cell concentration and depth of shade of the dyeing on the color removal process. Further resting cell assays were carried out to ascertain if an electron donor was required for the color removal process, and suggested that the cotton substrate could supply some reducing power to the biocatalyst, although dye reduction rates were maximal with added electron donor (formate). The Shewanella cells were also able to remove the color from dyed cotton fabric that was isolated inside a dialysis membrane to prevent contact with the cells. This indicates that Shewanella strain J18 143 is able to synthesize and excrete endogenous extracellular electron shuttles, eliminating the need for direct contact between the intracellular electron transport components and the extracellular terminal electron acceptors. The dyed cotton fabric was assessed visually, and by reflectance spectroscopy and environmental scanning electron microscopy.
\end{abstract}

Key words colour removal, bioreduction, biodegradation, bioremediation, electron-shuttling compounds, Shewanella

\author{
Carolyn I. Pearce ${ }^{1}$ and James T. Guthrie \\ Department of Colour Science. School of Chemistry. \\ University of Leeds, U.K.
}

Jonathan R. Lloyd

Williamson Centre for Molecular Environmental Science and the School of Earth. Atmospheric and Environmental Sciences, University of Manchester, U.K.
Shewanella strain J18 143 [1] is a rod-shaped Gram-negative bacterium with remarkable respiratory versatility, in common with other Shewanella species [2]. Shewanella strain J18 143 uses oxygen as the terminal electron acceptor during aerobic respiration. However, under anaerobic conditions, this bacterium can utilize an array of respiratory electron acceptors, including iron, nitrate, chromium salts, and azo compounds, some of which exist in the solid phase $[2,3]$. The ability of the bacterium to reduce organics and convert certain metal ions to the reduced, insoluble

\footnotetext{
${ }^{1}$ Corresponding author: current address: School of Earth, Atmospheric and Environmental Sciences, University of Manchester, UK, tel: +44 (0) 161275 3828; fax: +44(0)161 306 9361; e-mail: carolyn.pearce@manchester.ac.uk
} 
oxides suggests that Shewanella strain J18 143 can be used for the bioremediation of organic pollutants and metal pollutants under anaerobic conditions.

Color pollution in aquatic environments, caused by inefficient processes in the textile coloration industries, is an escalating problem. The use of whole bacterial cells to metabolize azo dyes, present in colored, aqueous wastewater, has been investigated extensively [4]. Research has shown that Shewanella strain J18 143 can remove the color from spent reactive azo dyebaths with considerable efficiency $[5,6]$, and can also have an effect on the color of azo/ ketohydrazone pigment dispersions in which the pigments are relatively insoluble [7]. During the reactive dyeing of cotton, reactive dyes form covalent bonds with the cotton fabric (Figure 1), limiting the intramolecular rotation within the dye molecule. In this form, the dye is no longer in solution and the azo bonds in the dye molecule are significantly less available for reduction by the Shewanella strain J18 143 cells. In this research, samples of cotton fabric dyed with C.I. Reactive Black 5 were used to determine the ability of the Shewanella strain J18 143 cells to reduce colored compounds covalently bonded to a solid substrate. C.I. Reactive Black 5 was chosen due to its well characterized bifunctional reactive azo dye structure [8] and because of its very large consumption rate in cotton reactive dyeing processes [9]. This bio-bleaching process, involving a bacterial catalyst, offers potential benefits to the color industry as the removal of color from dyed fabric opens up the potential for fabric re-use.

There are many precedents for the use of microbial agents in textile processes, particularly to replace the harsh chemicals that are normally required, thereby reducing their environmental impact. Cellulases are used to give cotton fabrics a soft, pre-washed feel and appearance, and are also used to replace pumice stones in "stone-washing" to produce the aged appearance of denim garments [10]. Lacasses are used to decolorize indigo and are important in the treatment and finishing of denim fabric [11]. Catalases are involved in the bleaching step [12] and lipases are used to remove lubricants, providing the fabric with greater absorbency for improved levels of dyeing [13].

Shewanella strain J18 143 cells contain an array of enzymes that could be of relevance to the textile coloration industry, in particular, enzyme activity that results in the removal of color from fabrics either to produce a faded, slightly worn look or to open up the possibility of fabric re-use. The removal of color from dyed fabrics necessitates an extension of the reducing capacity of Shewanella strain J18 143 to include the reduction of azo/ketohydrazone bonds when the dyes are no longer in solution, being bonded on to a solid substrate.

To determine whether or not the Shewanella strain J18 143 cells were capable of the extracellular reduction of the azo/ketohydrazone bonds in the dye molecule on the cotton, possibly via a mechanism involving electron shuttles, the cells were challenged with samples of cotton fabric dyed with C.I. Reactive Black 5. For the current work, anaerobic "resting" cell suspensions and growing cell cultures of our test organism were used to reduce the azo/ketohydrazone bonds in C.I. Reactive Black 5 on cotton fabric. Resting cell suspensions were subsequently used to carry out an investigation into the effect of a number of factors, including the concentration of cells in the resting cell assays, the depth of shade dyeing (\% mass of fiber (omf)) on the cotton fabric, the electron donor, and the addition of an exogenous extracellular electron-shuttling compound. The mechanism of reduction of C.I. Reactive Black 5 on cotton fabric using Shewanella strain J18 143 cells, involves the cleavage of the azo/ketohydrazone chromophore to form the correspond-

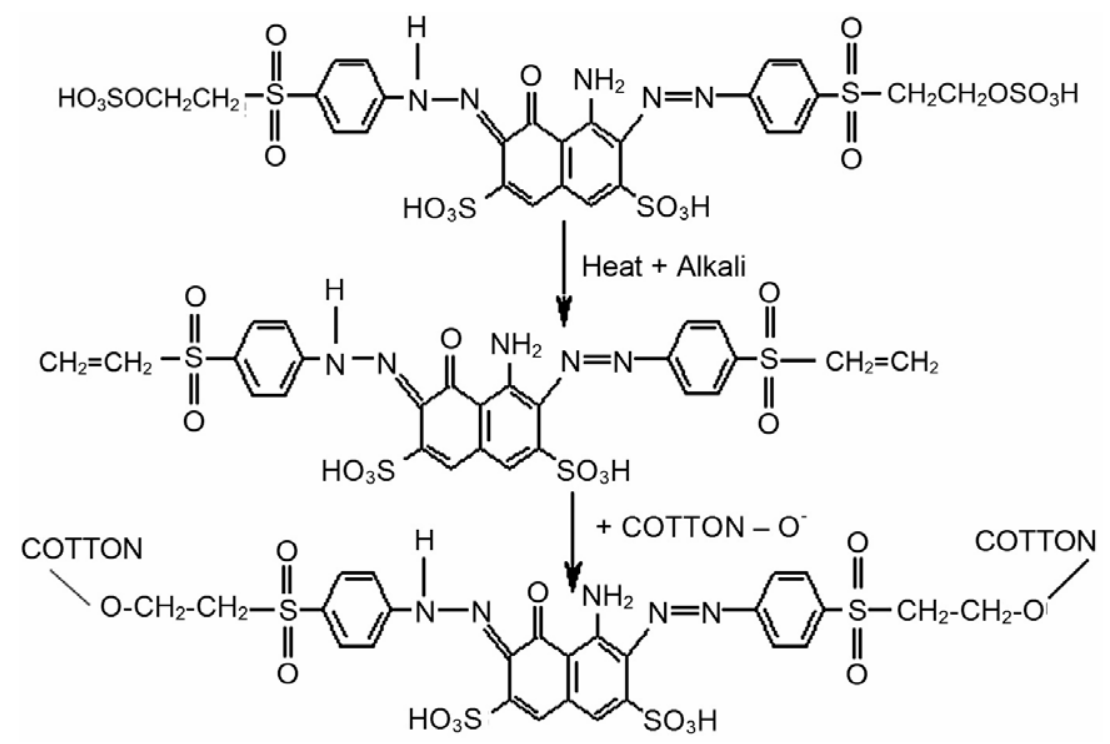

Figure 1 Formation of covalent bonds between C.I. Reactive Black 5) and cotton fabric during the dyeing process. 
Figure 2 Amines production upon reduction of C.I. Reactive Black 5 on cotton fabric.

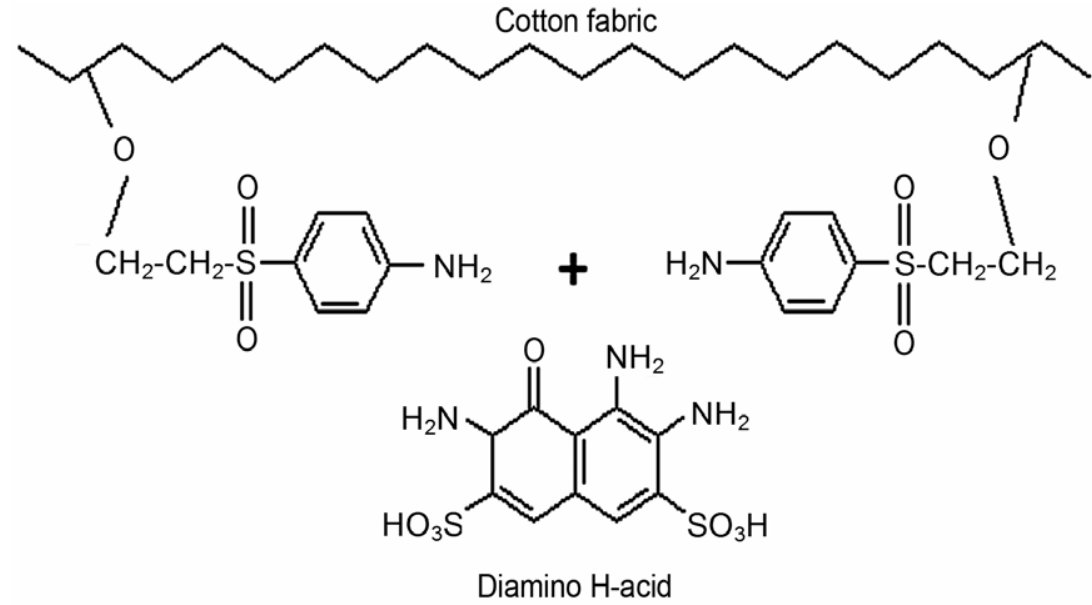

ing amines. If both the azo/ketohydrazone bonds in the C.I. Reactive Black 5 dye molecule are reduced, some of the amines produced will remain bonded on to the cotton, whereas others will be lost to the solution. The amine fragments and amines that would be produced by the reduction of the azo/ketohydrazone bonds in C.I. Reactive Black 5 on cotton fabric are shown in Figure 2.

The nitrous acid test for the elucidation of the constitution of dyestuffs, as described by Green [14], was used to determine the presence of these amino compounds bonded on to the cotton fabric. The test involves the diazotization of these amines, followed by coupling with $\beta$-naphthol. If amino compounds were present on the cotton fabric this diazotization and coupling process would result in a significant color change.

For application of Shewanella strain J18 143 cells as biocatalysts in an industrial bio-bleaching process, it would be advantageous to prevent direct contact between the biological component and the dyed fabric, thereby reducing contamination and preventing any potential damage to the fibers. To achieve this, the cells must be able to produce molecules that can transfer electrons from the cell, through a membrane, to the azo/ketohydrazone bonds in the dye molecule on the cotton. In this study, dyed fabric was separated from the cells using dialysis tubing to investigate the ability of the Shewanella strain J18 143 cells to release microbial electron-shuttling compounds. The related organism, $S$. oneidensis MR-1, has recently been shown to release reduced flavins as electron-shuttling compounds [15]. A comparison was also made between the rate of dye reduction with the exogenous extracellular electron shuttle AQDS, and with the microbially synthesized electron-shuttle. This method is similar to that employed by Moser and Nealson [16] to establish that direct contact between the cell and the sulfur electron acceptor was not required for sulfur reduction by S. oneidensis MR-1.

\section{Experimental}

All chemicals were of analytical grade and obtained from Sigma-Aldrich (Dorset, U.K.), unless otherwise stated. Cotton fabric was obtained from Whaleys (Bradford) Ltd (Bradford, U.K.). C.I. Reactive Black 5 was obtained from Dystar U.K. Ltd (Huddersfield, U.K.). Sandozin NIE was obtained from Clariant (Leeds, U.K.).

\section{Materials and Methods for the Dyeing of Cotton Fabric with Remazol Black B Dye}

The dyeing profile shown in Figure 3 was used to dye cotton fabric samples (10 g) with C.I. Reactive Black 5. The liquor ratio was 10:1. C.I. Reactive Black $5(0.025 \mathrm{~g}$ for $0.25 \%$ omf, $0.1 \mathrm{~g}$ for $1 \% \mathrm{omf}, 0.3 \mathrm{~g}$ for $3 \% \mathrm{omf}, 0.5 \mathrm{~g}$ for $5 \% \mathrm{omf}$, and $0.8 \mathrm{~g}$ for $8 \% \mathrm{omf}$ ) was added to a solution of sodium sulfate $\left(8 \mathrm{~g} 100 \mathrm{~cm}^{-3}\right.$ of distilled water $)$. This dyebath $\left(100 \mathrm{~cm}^{3}\right)$ was then added to dyeing tubes containing cotton fabric $(10 \mathrm{~g})$. The dyeing tubes were placed in a Pyrotic-S dyeing machine and the samples were dyed for 30 minutes at $60^{\circ} \mathrm{C}$. Trisodium phosphate $(2 \mathrm{~g})$ was added and dyeing was continued for 60 minutes at $60^{\circ} \mathrm{C}$. The cotton fabric was rinsed in cold water to remove excess dye and returned to the dyeing tubes. The non-ionic surfactant Sandozin NIE $\left(2 \mathrm{gdm}^{-3}, 150 \mathrm{~cm}^{3}\right)$ was added to the dyeing tubes and the dye was "soaped-off" at $100^{\circ} \mathrm{C}$ for 15 minutes. After the cotton fabric had cooled down, it was thoroughly rinsed and dried.

A calibration curve of the reflectance values versus the mass of dye on the cotton fabric was constructed for cotton fabric dyed with C.I. Reactive Black 5 by preparing a series of fabric samples dyed with a known mass of dye. To determine the mass of dye on the cotton fabric, the absorbance of the initial dye bath solution, the final dye bath solution, 


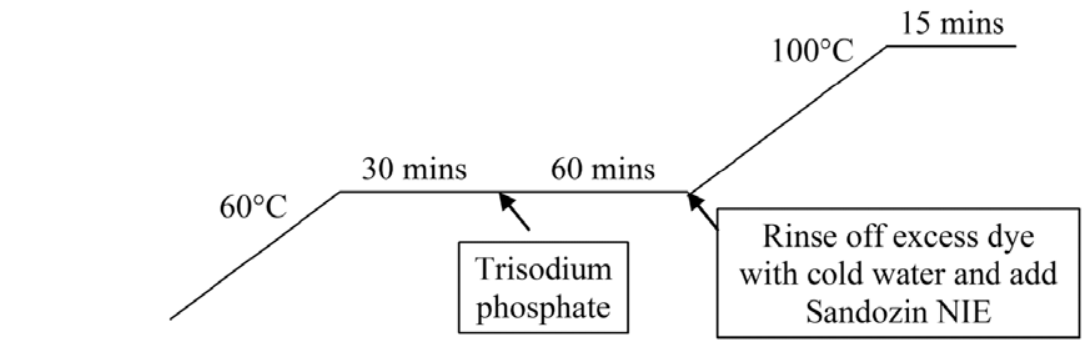

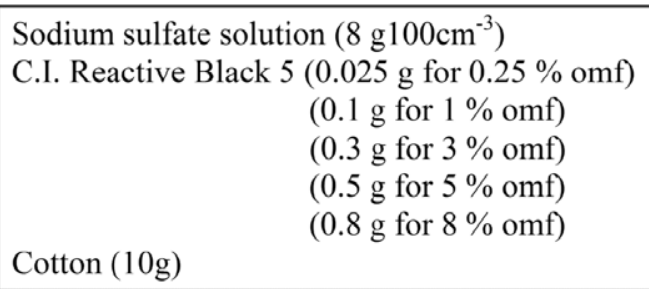

Liquor ratio $=10: 1$

Dyebath volume $=100 \mathrm{~cm}^{3}$
Figure 3 Dyeing profile for C.I. Reactive Black 5. and the rinsing solutions were measured at the $\lambda_{\max }$ for C.I. Reactive Black 5 (597 nm) using a Specord S100 spectrophotometer. The mass of dye in each of the solutions was determined using a calibration curve. The mass of dye on the cotton fabric was calculated using the following equation:

mass of dye in initial dye bath solution $(\mathrm{mg})$

- [mass of dye in final dye bath solution $(\mathrm{mg})$

+ mass of dye in rinsing solutions (mg)]

$=$ mass of dye on cotton fabric $(\mathrm{mg})$

This procedure was carried out for a number of dyed fabric samples, at each \% omf, to obtain an average value. The reflectance of the dyed cotton samples, at $597 \mathrm{~nm}$, over a depth of shade range of $0.25 \%$ omf to $8 \%$ omf was measured using a Minolta spectrophotometer CM-3600d. The $\mathrm{K} / \mathrm{S}$ system values for the dyed cotton fabric samples were determined from the reflectance measurements and used to construct the calibration curve.

\section{Reduction of C.I. Reactive Black 5 on Cotton Fabric Using Anaerobic Resting Cell Suspensions, or Using Anaerobic Growing Cell Cultures, of Shewanella Strain J18 143}

To carry out the reduction of C.I. Reactive Black 5 on cotton fabric using growing cell cultures, cotton fabric samples ( $2 \mathrm{~g})$, dyed with C.I. Reactive Black 5 (1\% omf), were sterilized at $121^{\circ} \mathrm{C}$ for 15 minutes, and transferred aseptically to $100 \mathrm{~cm}^{3}$ bottles containing $90 \mathrm{~cm}^{3}$ of sterile tryptone soy broth $\left(30 \mathrm{gdm}^{-3}\right.$ [distilled water]), supplemented with 21 $\mathrm{mM}$ sodium formate as an electron donor. The bottles were sealed with $20 \mathrm{~mm}$ butyl rubber stoppers and the headspace was filled with nitrogen. The bottles were inoculated with an overnight culture in late log/early stationary phase $\left(9 \%\right.$ [vol/vol] $\left.9 \mathrm{~cm}^{3}\right)$ and incubated at $30^{\circ} \mathrm{C}$, without shaking.

To carry out the reduction of C.I. Reactive Black 5 on cotton fabric using pre-grown resting cell suspensions, cotton fabric samples ( $2 \mathrm{~g})$ dyed with C.I. Reactive Black $5(1 \%$ omf) were added to a series of vials (volume $20 \mathrm{~cm}^{3}$ ). To determine the effect of depth of shade of dyeing on the reduction of C.I. Reactive Black 5 on cotton fabric, samples of cotton fabric $(2 \mathrm{~g})$, dyed with C.I. Reactive Black 5 $(0.25 \%$ omf, $1 \%$ omf, and $8 \%$ omf, respectively) were added. A sodium formate solution $(1 \mathrm{M})$ was added to the vials as the electron donor (final concentration, $21 \mathrm{mM}$ ). To determine the effect of an exogenous extracellular electron shuttle on the reduction of C.I. Reactive Black 5 on cotton fabric using Shewanella strain J18 143 cells, a solution of anthraquinone-2,6-disulfonate (AQDS) (10 mM) was added (final concentration, $100 \mu \mathrm{M}$ ). The assay solutions were diluted to $7.2 \mathrm{~cm}^{3}$ with $10 \mathrm{mM}$ phosphate buffer, $\mathrm{pH}$ 7.0, supplemented with $0.1 \mathrm{M} \mathrm{NaCl}$ (phosphate buffered saline (PBS)). The vials were sealed and the headspace was filled with nitrogen. Anaerobic resting cell suspensions were injected into the sealed anaerobic vials and incubated at $30^{\circ} \mathrm{C}$ without shaking. To determine the optimum amount of the cell suspension for the reduction of C.I. Reactive Black 5 on cotton fabric using resting cell suspensions of Shewanella strain J18 143, resting cell suspensions $\left(0.8 \mathrm{~cm} 3,8.0 \mathrm{~cm}^{3}\right.$, and $14.88 \mathrm{~cm}^{3}$, respectively) were 
injected. A sample of dyed cotton fabric was also incubated under the same conditions in the absence of cells. A suspension of $8 \mathrm{~cm}^{3}$ of anaerobic resting cells was used in all subsequent reduction experiments involving dyed cotton fabric to produce a final cell suspension of approximately $50 \%(\mathrm{v} / \mathrm{v})$. Samples were removed for protein analysis using a bicinchoninic acid assay kit (Sigma), as described by Smith et al. [17]. In order to calculate the amount of biomass from the protein analysis, it was assumed that the biomass contained approximately $55 \%$ protein [18]. These experiments were carried out in triplicate.

The dyed cotton fabric was sampled regularly. The samples were washed in cold water and dried. The reflectance of the dyed cotton fabric samples was measured before and after incubation, using a Minolta spectrophotometer CM$3600 \mathrm{~d}$ with undyed cotton fabric as the standard. Analysis of the dyed cotton fabric samples was also carried out using a Phillips XL30 ESEM ODP scanning electron microscope, to obtain more information concerning the distribution of the Shewanella strain J18 143 cells on the surface of the cotton fibers.

To determine whether or not the cotton fabric itself could donate the electrons necessary for the reduction of C.I. Reactive Black 5, further resting cell assays were carried out. Solutions of C.I. Reactive Black 5 were added to a series of anaerobic cuvettes to a final concentration of 27 $\mu \mathrm{M}$. When sodium formate was used as an electron donor, solutions $(1 \mathrm{M})$ were added to the sample vials (final concentration, $21 \mathrm{mM})$. When dyed cotton fabric (1\% omf) and undyed cotton fabric fiber were used as electron donors, samples $(0.1 \mathrm{~g})$ were added to the cuvettes. The assay solutions were diluted to $3.6 \mathrm{~cm}^{3}$ using PBS $(10 \mathrm{mM}, \mathrm{pH} 7)$. The cuvettes were sealed with rubber stoppers and the headspace was filled with nitrogen and anaerobic resting cell suspensions $\left(0.2 \mathrm{~cm}^{3}\right)$ were injected. The samples were incubated at $30^{\circ} \mathrm{C}$, without shaking. The absorbance of the solutions in the cuvettes was measured periodically at the $\lambda_{\max }$ for C.I. Reactive Black $5(597 \mathrm{~nm})$ using a Specord S100 spectrophotometer fitted with a temperature-controlled cuvette changer. The absorbance of a "blank" solution containing all the assay solutions other than the colorant was also measured and used to normalize the absorbance data. Each experiment was carried out in triplicate.

\section{Characterization of Amines Arising from the Reduction of C.I. Reactive Black 5 on Cotton Fabric Using Anaerobic Resting Cell Suspensions of Shewanella Strain J18 143}

Samples of cotton fabric $(1 \mathrm{~g})$ dyed with C.I. Reactive Black 5 (1\% omf) were added to a series of $10 \mathrm{~cm}^{3}$ autosampler vials. A sodium formate solution $(1 \mathrm{M})$ was added to the vials as the electron donor (final concentration, $21 \mathrm{mM}$ ). The assay solutions were diluted to $9.0 \mathrm{~cm}^{3}$ using PBS (10 $\mathrm{mM}, \mathrm{pH} 7)$. The vials were sealed and the headspaces were filled with nitrogen. Anaerobic resting cell suspensions $\left(0.5 \mathrm{~cm}^{3}\right)$ were injected into the sealed anaerobic vials and they were incubated at $30^{\circ} \mathrm{C}$, without shaking, for 7 days. After this time, the vials were centrifuged using a Jouan Centrifuge C3-12 (relative centrifugal force of $1771 \times g$ for 10 minutes, at ambient temperature). Sodium dithionite $\left(\mathrm{Na}_{2} \mathrm{~S}_{2} \mathrm{O}_{4}\right)$ in an alkaline solution is known to reduce azo bonds chemically to produce the corresponding amines [14]. Thus, to act as a guide for the biological reduction, samples of C.I. Reactive Black 5 on cotton fabric were chemically reduced using sodium dithionite. A diazotization and coupling process was also employed for the characterization of the amines that were bound to the surface of the biogenically reduced dyed cotton fabric samples. The reduced cotton fabric was immersed in $10 \%$ hydrochloric acid solution

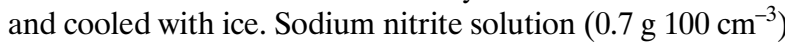
was added. The dyed cotton fabric was removed, rinsed and immersed in a solution of $\beta$-naphthol in 5\% sodium hydrox-

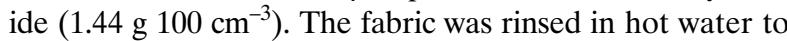
allow the coupling to take place, and then dried. The reflectance spectrum of each of the cotton fabric samples was measured after this diazotization and coupling process.

\section{Reduction of C.I. Reactive Black 5 on Cotton Fabric, Through a Dialysis Membrane, Using Anaerobic Resting Cell Suspensions of Shewanella Strain J18 143. With and Without AQDS}

The dyed cotton fabric was encapsulated in a dialysis membrane to provide evidence that the Shewanella strain J18 134 cells are capable of producing microbial electron shuttles, giving a vital insight into the mechanism by which the cells interact with external electron acceptors. A sodium formate solution $(1 \mathrm{M})$ was added to a series of $10 \mathrm{~cm}^{3}$ autosampler vials as the electron donor to a final concentration of $21 \mathrm{mM}$. A solution of AQDS $(10 \mathrm{mM})$ was added as an exogenous extracellular electron shuttle to some control vials (final concentration, $100 \mu \mathrm{M}$ ). The assay solutions were diluted to $8.1 \mathrm{~cm}^{3}$ with PBS (10 mM, pH 7). Visking dialysis tubing (15 cm in length) was soaked in hot water for 15 minutes and sealed at one end. Assay solution $\left(2.25 \mathrm{~cm}^{3}\right)$ and samples of cotton fabric $(0.4 \mathrm{~g})$, dyed with C.I. Reactive Black 5 (1\% omf), were added to the dialysis tubing. The tubing was sealed and added to the vials. The vials were sterilized in a pressure cooker for 15 minutes at $121^{\circ} \mathrm{C}$ and then allowed to cool. The vials were then sealed. The headspaces were filled with nitrogen and anaerobic resting cell suspensions $\left(4.0 \mathrm{~cm}^{3}\right)$ were injected into the sealed anaerobic vials (Figure 4$)$. The vials were incubated at $30^{\circ} \mathrm{C}$, without shaking, for 8 days. Sacrificial vials were opened every 2 days. The dyed cotton fabric samples were removed from the dialysis tubing, washed three times in cold water $\left(150 \mathrm{~cm}^{3}\right)$ and dried at $30^{\circ} \mathrm{C}$ for 2 hours. Then the reflectance spectrum of each of the sam- 


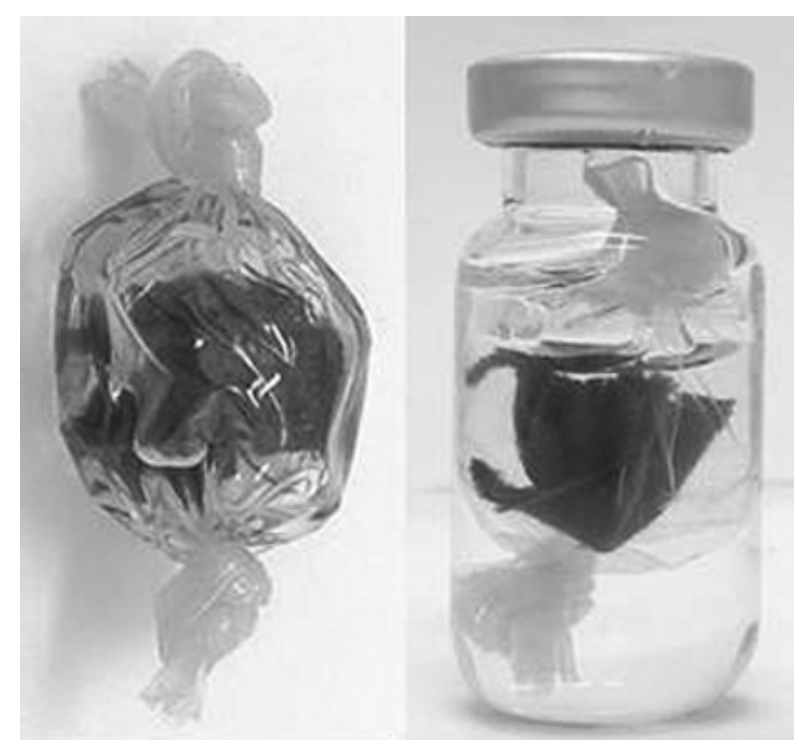

Figure 4 Experimental set-up for dialysis tubing assays.

ples was measured. The experiment was carried out in triplicate.

\section{Results and Discussion}

\section{Reduction of C.I. Reactive Black 5 on Cotton Fabric Using Anaerobic Resting Cell Suspensions or Anaerobic Growing Cell Cultures of Shewanella Strain J18 143}

To compare the reducing activity of growing cell cultures and washed anaerobic resting cell suspensions, the Shewanella strain J18 143 cells were challenged with cotton fabric samples that had been dyed with C.I. Reactive Black 5. The reflectance spectrum of each of the fabric samples was measured before and after the incubation period of 1 week, using a reflectance spectrophotometer. The results were used to calculate the $\mathrm{K} / \mathrm{S}$ value, which is related to the amount of dye on the fabric. The K/S values, over a range of wavelengths from $400 \mathrm{~nm}$ to $700 \mathrm{~nm}$, before and after the stated incubation period, are shown in Figure 5. A substantial change in the $\mathrm{K} / \mathrm{S}$ values was observed with both the growing cell cultures and the washed anaerobic resting cell suspensions, over a period of 7 days, corresponding to the removal of a large quantity of the dye to produce a much lighter shade on the fabric. These results suggest that the cells were able to reduce the azo/ketohydrazone bonds in situ on the fabric. The growing cell cultures had a slightly

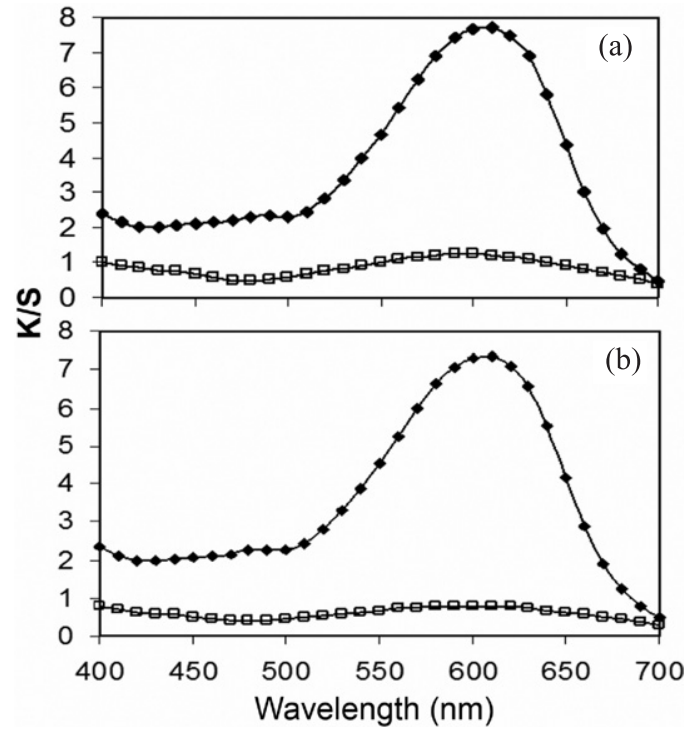

Figure 5 C.I. Reactive Black 5 on cotton fabric (1\% omf) before ( $\checkmark$ ) and after $(\square) 1$ week's exposure to (a) anaerobic resting cell suspensions of Shewanella strain J18 143 in phosphate-buffered saline, or (b) anaerobic growing cell cultures of Shewanella strain J18 143 in tryptone soy broth at $30^{\circ} \mathrm{C}$, both supplied with sodium formate.

higher activity and reduced the K/S value to less than 1 at the $\lambda_{\max }$ for C.I. Reactive Black $5(597 \mathrm{~nm})$. However, the extent of dye removal from the fabric over 1 week was sufficient, using the washed resting cell suspensions, for the cells to be used in this form in subsequent reduction experiments.

Cotton fabric dyed with C.I. Reactive Black 5 to a deep shade ( $8 \%$ omf) was exposed to both growing and resting cells to give an indication of the extent of color removal that was achievable. Figure 6 shows that, over a longer time period, it is possible to remove all of the dye from the fabric to produce a white shade. The near-white color visible in Figure 6(b), after 8 weeks, compared with the bluishgray color visible in Figure 6(a) shows that the growing cell cultures were also more active than the resting cell suspensions over longer periods of exposure. This is a result of the variation in cell concentration as the washed anaerobic cell suspensions of Shewanella strain J18 143 were introduced at a known concentration, but the concentration of cells in the growing anaerobic cultures varies depending on the growth phase. Also, nutrients from the growth medium will sorb on to the solid fabric substrate, increasing the nutrient levels in the surface micro-environment relative to the bulk solution and allowing the growing cells to colonize the sur- 


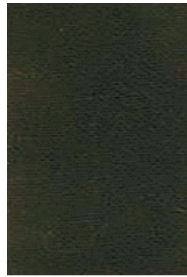

Week 0

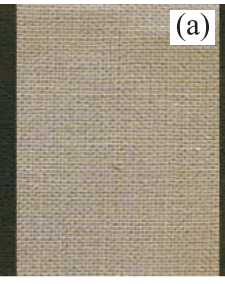

Week 8

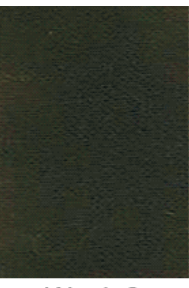

Week 0 (b)

Figure 6 Photographs of C.I. Reactive Black 5 on cotton fabric ( $8 \%$ omf) before and after incubation with anaerobic resting cell suspensions of Shewanella strain J18 143 (a) and with anaerobic growing cell cultures of Shewanella strain J18 143 (b). face to produce a biofilm. This facilitates direct electron transfer to the dye substrate, resulting in a higher level of color removal compared with the planktonic resting cells in the buffer. This effect could also be enhanced by the localized production of extracellular flavin redox mediators [15] in the growing cultures.

To gain a greater understanding of these effects, fabric samples that had been incubated without cells (Figure 7(a)), with resting cells (Figure 7(b)) or with growing cells (Figure 7(c)), were analyzed using an environmental scanning electron microscope. A limited amount of cellular material can be seen on the surface of the fibers that were exposed to the resting cells (Figure 7(b)). However, a much greater number of intact rod-shaped Shewanella cells are visible on the fibers incubated with growing cells (Figure 7(c)). The morphology of the growing cells appears to have been influenced by their presence in a biofilm. The apparent elongation of the cells is in accordance with the results obtained by several other investigators who have observed the predominance of filamentous organisms in biofilms, particularly under oxygen limited conditions [19]. The greater number of intact cells visible on the surface of the fibers in Figure 7(c) provides an explanation of why the growing cell cultures were able to remove the color from the cotton fabric more efficiently than the limited amount of biomass present on the fabric in the resting cell suspensions (Figure 7(b)).

The removal of color from the cotton fabric, illustrated in Figure 6, is surprisingly consistent when considering the micrographs in Figure 7, which show that the Shewanella cells, in both the resting cell suspensions and the growing cell cultures, do not cover the whole surface of the fibers. This lack of coverage suggests that the cells employ a mechanism other than direct physical contact between the cells and the dye molecules to reduce the dye. Results from the microbial reduction of highly sulfonated, high molecular weight azo dyes [1] and virtually insoluble pigments [7] indicate that this mechanism involves an effective reducing environment, created by the cells, in which it is possible to transfer electrons to all the available electron acceptors tested. The uniformity of dye reduction achieved on the cotton demonstrates the efficiency of the reducing environment produced by the Shewanella strain J18 143 cells, even in the presence of relatively low cell numbers.

\section{Factors Affecting the Reduction of C.I. Reactive Black 5 on Cotton Fabric Using Anaerobic Resting Cell Suspensions of Shewanella Strain J18 143}

Optimization of a number of process variables was carried out, including the concentration of cells in the resting cell assays, the depth of shade dyeing (\% omf) on the cotton fabric, the electron donor used, and the addition of an exogenous extracellular electron-shuttling compound, on the removal of color from reactively dyed cotton fabric.
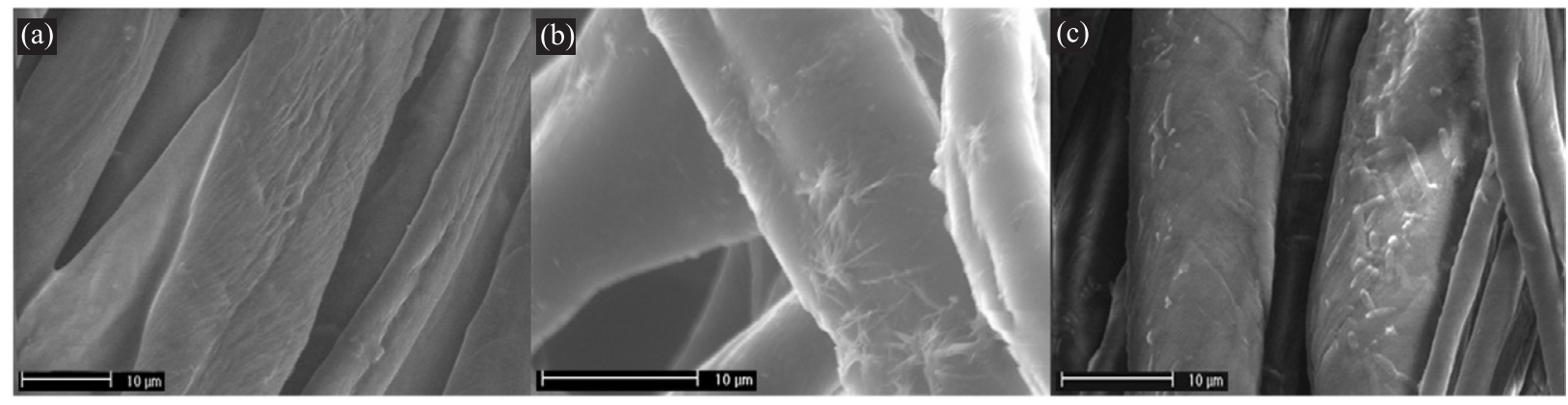

Figure 7 Environmental scanning electron micrographs of cotton fabric dyed with C.I. Reactive Black 5 after 20 hours incubation at $30^{\circ} \mathrm{C}$ without cells (a), with anaerobic resting cell suspensions (b), and with anaerobic growing cell cultures (c). 


\section{Effect of Amount of Cell Suspension on the Reduction of C.I. Reactive Black 5 on Cotton Fabric}

The effect of the amount of cell suspensions on the rate of color removal was determined by challenging different amounts of washed, anaerobic cell suspensions, over a period of 1 week, with cotton fabric samples that had been dyed using C.I. Reactive Black 5 (1\% omf) at pH 7 and $30^{\circ} \mathrm{C}$. No change in the color of the dyed fabric was observed when Shewanella cells were not included in the experiment. However, even low numbers of cells resulted in significant reduction of the amount of dye on the fabric, with a reduction rate of $31 \mathrm{mg}$ dye $0.1 \mathrm{~g}^{-1}$ (biomass) week ${ }^{-1}$. When the amount of cell suspension used in the experiment was increased to $1.1 \mathrm{mg} \mathrm{cm}^{-3}$, the $\mathrm{K} / \mathrm{S}$ value at the $\lambda_{\max }$ for C.I. Reactive Black $5(597 \mathrm{~nm})$ was decreased to an even greater extent and the reduction rate increased to $49 \mathrm{mg}$ dye $1.1 \mathrm{~g}^{-1}$ (biomass) week ${ }^{-1}$. From these results, it can be stated that the extent of color removal from the dyed cotton fabric was greater with higher numbers of Shewanella cells. However, increasing the amount of cell suspension to $2.1 \mathrm{mg} \mathrm{cm}^{-3}$ had a relatively small effect on the extent of color removal and a very similar reduction rate of $51 \mathrm{mg}$ dye $2.1 \mathrm{~g}^{-1}$ (biomass) week ${ }^{-1}$ was achieved, suggesting that the rate-limiting step with this number of cells was the amount of available electron acceptor. The amount of cell suspension used in all subsequent experiments was $1.1 \mathrm{mg} \mathrm{cm}^{-3}$.

\section{Effect of Depth of Shade of Dyeing (\% omf) on the Reduction of C.I. Reactive Black 5 on Cotton}

\section{Fabric}

The effect of depth of shade dyeing on the reduction rate was assessed to determine the ability of Shewanella strain J18 143 cells to recognize very small amounts of C.I. Reactive Black 5 on cotton fabric, and to remove color from fabrics of a lighter shade, as well as to achieve color removal from the fabric samples with very dark, almost black, shades produced by the textile coloration industry. Washed anaerobic cell suspensions $\left(1.1 \mathrm{mg} \mathrm{cm}^{-3}\right)$, were challenged with cotton fabric samples, dyed using C.I. Reactive Black 5 at three different depths of shade $(0.25 \%$ omf, $1 \%$ omf, and $8 \%$ omf), at neutral $\mathrm{pH}$ and $30^{\circ} \mathrm{C}$ for 1 week. The results (Figure 8) show that the Shewanella strain J18 143 cells are capable of removing the color from cotton fabric samples exhibiting a variety of different shades. The actual amount of C.I. Reactive Black 5 on the fabric that was reduced by the cells over a period of a week was calculated (milligrams of dye reduced per gram [dry weight] of cells). In Figure 8(a), it can be seen that the cells were able to reduce the $\mathrm{K} / \mathrm{S}$ value for the lightest shade $(0.25 \%$ omf $)$ to almost zero. The actual amount of C.I. Reactive Black 5 that was reduced on the fabric over the incubation period was $10.4 \mathrm{mg}$ dye $\mathrm{g}^{-1}$ (biomass) week ${ }^{-1}$. When a fabric sample with a depth of shade of $1 \%$ omf was
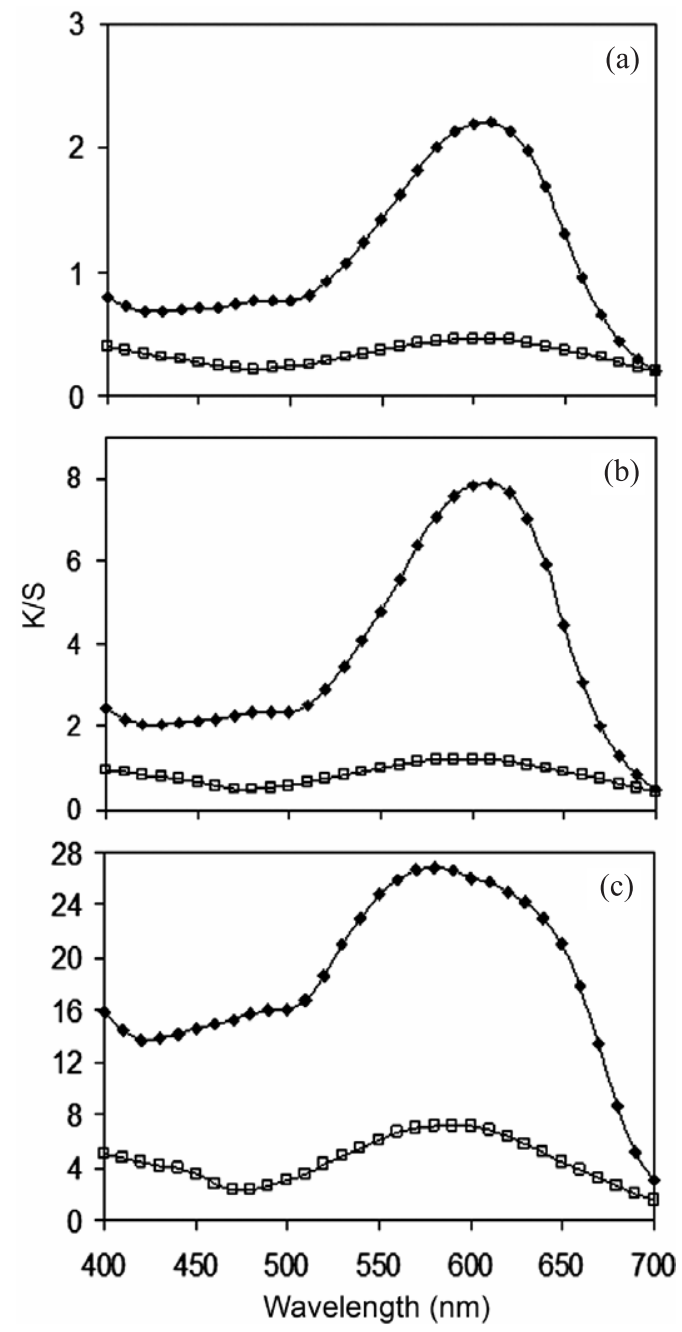

Figure 8 Reduction of C.I. Reactive Black 5 on cotton fabric with (a) $0.25 \%$ omf. (b) $1 \%$ omf, and (c) $8 \%$ omf before $(\checkmark)$ and after $(\square) 1$ week's exposure to anaerobic resting cell suspensions of Shewanella strain $J 18143\left(1.1 \mathrm{mg} \mathrm{cm}^{-3}\right)$ in phosphate-buffered saline at $30^{\circ} \mathrm{C}$. supplied with sodium formate.

used in the experiment (Figure 8(b)), the $\mathrm{K} / \mathrm{S}$ value remaining after the incubation period was slightly higher than that observed with the lightest shade, but five times more dye was reduced by the cells $\left(51 \mathrm{mg} \mathrm{dye}^{-1}\right.$ (biomass) week $^{-1}$ ). When a fabric sample with a very intense depth of shade $(8 \%$ omf) was used in the experiment, incubation with the cells resulted in the removal of $156 \mathrm{mg}$ dye $\mathrm{g}^{-1}$ (biomass) week ${ }^{-1}$ from the fabric, as shown in Figure 8(c), with some color remaining on the fabric. 
Figure 9 Reduction of C.I. Reactive Black 5 on cotton fabric ( $1 \%$ omf) using anaerobic resting cell suspensions of Shewanella strain J18 143 in phosphate-buffered saline at $30^{\circ} \mathrm{C}$. supplied with no electron donor $(X)$, or supplied with formate $(\diamond)$, dyed cotton $(\square)$, or undyed cotton $(\boldsymbol{\Delta})$ as the electron donor. Absorbance data normalized using a standard containing no dye.

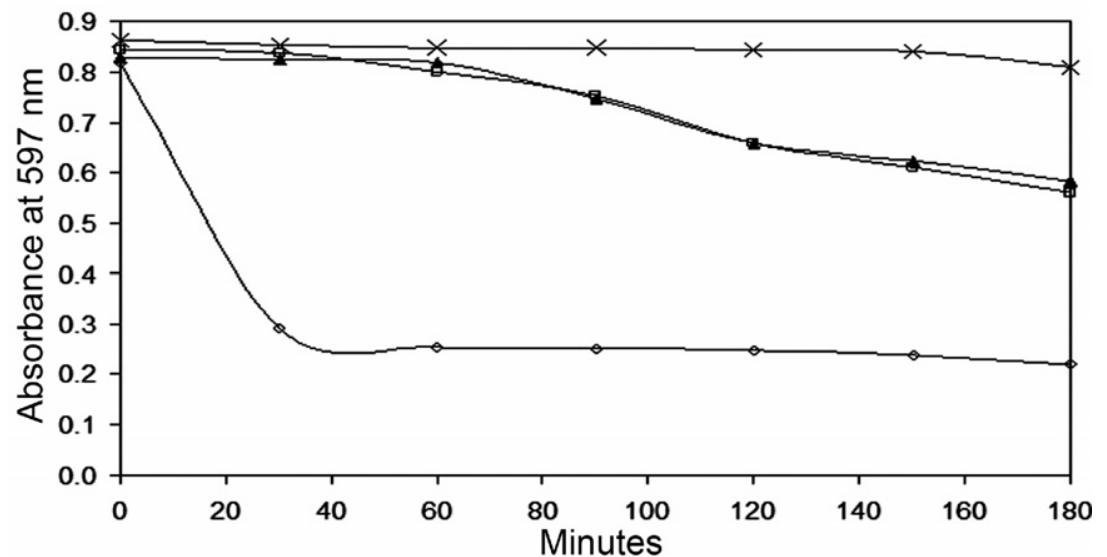

These results are promising as they show that the Shewanella strain J18 143 cells are able to reduce C.I. Reactive Black 5 on cotton at three different depths of shade.

\section{Effect of Electron Donor on the Reduction of C.I. Reactive Black 5 on Cotton Fabric}

Sodium formate has been shown to be the most efficient electron donor for C.I. Reactive Black 5 reduction under anaerobic conditions, when compared with other organic acid anions (lactate or acetate) and nicotinamide adenine dinucleotide (NADH) [1]. However, the expense associated with the addition of this external electron donor could be avoided if the cells were able to use an alternative source of electrons, such as the cotton fabric itself. Therefore, washed anaerobic cell suspensions $\left(1.1 \mathrm{mg} \mathrm{cm}^{-3}\right)$, were challenged with cotton fabric samples dyed using C.I. Reactive Black 5 (1\% omf), either with or without sodium formate as the electron donor, at neutral $\mathrm{pH}$ and $30^{\circ} \mathrm{C}$ for 1 week. A very similar level of color removal was achieved both with and without the addition of the exogenous electron donor, with a reduction rate of $51 \mathrm{mg}$ dye $\mathrm{g}^{-1}$ (biomass) week ${ }^{-1}$ in the presence of sodium formate, and a reduction rate of 50 ${\mathrm{mg} \text { dye } \mathrm{g}^{-1} \text { (biomass) week }}^{-1}$ in the absence of sodium formate. These results suggest that the cotton fabric itself could provide the electrons necessary for dye reduction by the Shewanella cells. To confirm whether or not the Shewanella strain J18 143 cells could use the cotton as an electron donor, washed, anaerobic cell suspensions were challenged with a solution of C.I. Reactive Black $5(25 \mu \mathrm{M})$ and supplied with either sodium formate, dyed cotton or undyed cotton. The change in absorbance of the C.I. Reactive Black 5 solution, as a result of reduction by Shewanella strain J18 143 cells, supplied with different electron donors over a period of 180 minutes, is shown in Figure 9. It can be seen that both the dyed cotton and the undyed cotton had some electron donating capacity when compared with the control that did not contain an electron donor. However, there was an initial lag phase before microbial dye reduction took place when cotton was used as the electron donor. Also, the microbial reduction rate in the presence of sodium formate was much faster, suggesting that electron donor character was the rate-limiting factor in these experiments. The results show that it is possible for the Shewanella strain J18 143 cells to use the cotton fabric as the electron donor for the reduction of C.I. Reactive Black 5, over the relatively long timescale of the experiment. Cotton fabric is composed of $87-90 \%$ cellulose and simple carbohydrates such as cellulose are known to act as electron donors in microbial processes. However, there are no potential cellulase genes in the Shewanella genome sequence, suggesting that there may be other bioavailable organics associated with the cotton.

\section{Effect of an Exogenous Extracellular Electron Shuttle on the Reduction of C.I. Reactive Black 5 on Cotton Fabric}

Azo dye- and azo/ketohydrazone pigment-reduction rates can be considerably improved by the addition of an exogenous extracellular electron shuttle, such as AQDS [1]. The addition of AQDS should also improve the reduction of C.I. Reactive Black 5 on cotton fabric, as the rate-limiting step may involve the accessibility of the dye molecules to the reducing equivalents produced by the cells. To determine the effect of AQDS on the rate of reduction, washed anaerobic Shewanella strain J18 143 cells $\left(1.1 \mathrm{mg} \mathrm{cm}^{-3}\right)$ were challenged with cotton fabric samples that were dyed using C.I. Reactive Black 5 (1\% omf), with and without AQDS, at $\mathrm{pH}$ 7 and $30^{\circ} \mathrm{C}$ over a period of 7 days. The rates of reduction over the initial 24 hours were calculated to be $44.6 \mathrm{mg}$ dye $\mathrm{g}^{-1}$ (biomass) day $^{-1}$ in the presence of AQDS and $26.1 \mathrm{mg}$ dye $\mathrm{g}^{-1}$ (biomass) day $^{-1}$ in the absence of AQDS, emphasizing that the reduction rate was considerably improved by the addition of an exogenous extracellular electron shuttle. 


\section{Analysis of the Products Arising from the Reduction of C.I. Reactive Black 5 on Cotton Fabric Using Anaerobic Resting Cell Suspensions of Shewanella Strain J18 143}

The reductive cleavage of azo dyes in solution by Shewanella strain J18 143 under anaerobic conditions to form the corresponding amines has been shown previously [1]. To determine whether a similar mechanism is employed for the reduction of C.I. Reactive Black 5 on cotton fabric, the products obtained from the microbial reduction of C.I. Reactive Black 5 on cotton fabric using Shewanella strain J18 143 cells were compared with those obtained from the chemical reduction of the dyed cotton fabric using sodium dithionite. It is known that sodium dithionite destroys the azo/ketohydrazone chromophore by reductive cleavage of the nitrogen-nitrogen bond [14]. The K/S values for the fabric samples, after 7 days incubation with either sodium dithionite or Shewanella strain J18 143 cells, are shown in Figure 10. From the similarity of the K/S values (Figure 10), it can be suggested that the Shewanella strain J18 143 cells also remove the color from C.I. Reactive Black 5 on cotton fabric by a reductive cleavage mechanism. The higher K/S value at $597 \mathrm{~nm}$ and the noticeable dark blue patches on the fabric in Figure 10(a) confirm that the amount of dye remaining on the fabric sample that had been chemically reduced was greater than the amount of dye remaining on the fabric sample that had been biologically reduced, indicating that bio-bleaching is more effective than using a chemical reducing agent.

Characterization of Amines Arising from the Reduction of C.I. Reactive Black 5 on Cotton Fabric Using Anaerobic Resting Cell Suspensions of Shewanella Strain J18 143

In order to characterize the products from the biological reduction mechanism, the nitrous acid test [14] was used to determine the presence of amino compounds bonded on to the cotton fabric. It was thought that this test would indicate that one or both of the azo/ketohydrazone bonds in the dye molecule had been cleaved to leave the $P$-aminophenyl- $\beta$ -

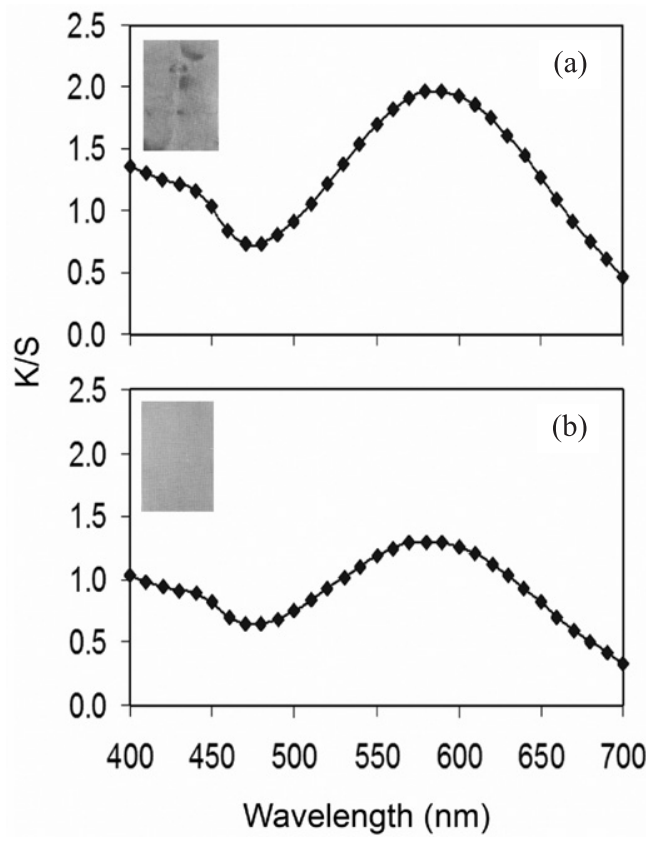

Figure $10 \mathrm{~K} / \mathrm{S}$ values and images for C.I. Reactive Black 5 on cotton fabric (1\% omf) after 7 days incubation at $30^{\circ} \mathrm{C}$ with sodium dithionite (a) and Shewanella strain J18 143 (b).

hydroxyethylsulfone sulfuric ester (para-base) units attached to the cotton, as suggested previously.

Figure 11 shows a sample of cotton fabric before biological reduction, after biological reduction, and after the diazotization of any available amine groups on the reduced cotton fabric, followed by coupling with $\beta$-naphthol. The C.I. Reactive Black 5 molecule itself contains an amine group prior to reduction. Therefore, the diazotization and coupling process was also carried out with a sample of dyed cotton fabric that had not been biologically reduced. Very little color change was observed with this fabric sample, suggesting that the amine group in the C.I. Reactive Black

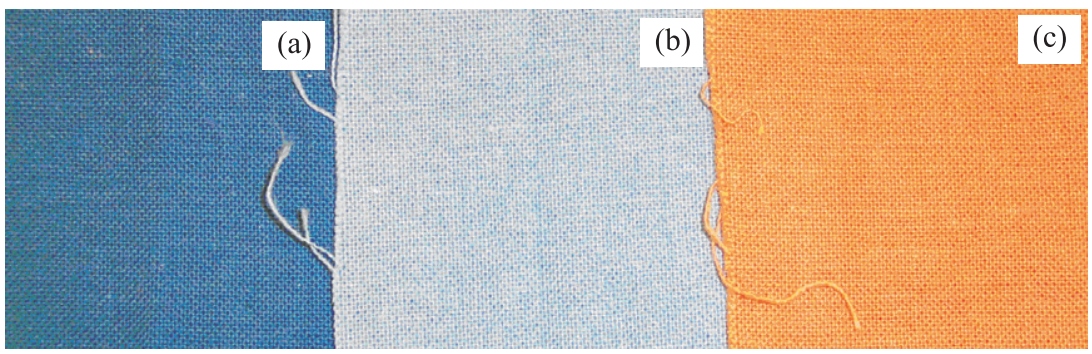

Figure 11 Photographs of C.I. Reactive Black 5 on cotton fabric ( $1 \%$ omf) before (a) and after (b) incubation with anaerobic resting cell suspensions of Shewanella strain $\mathrm{J} 18143$ at $30^{\circ} \mathrm{C}$, and (c) after diazotization and coupling. 

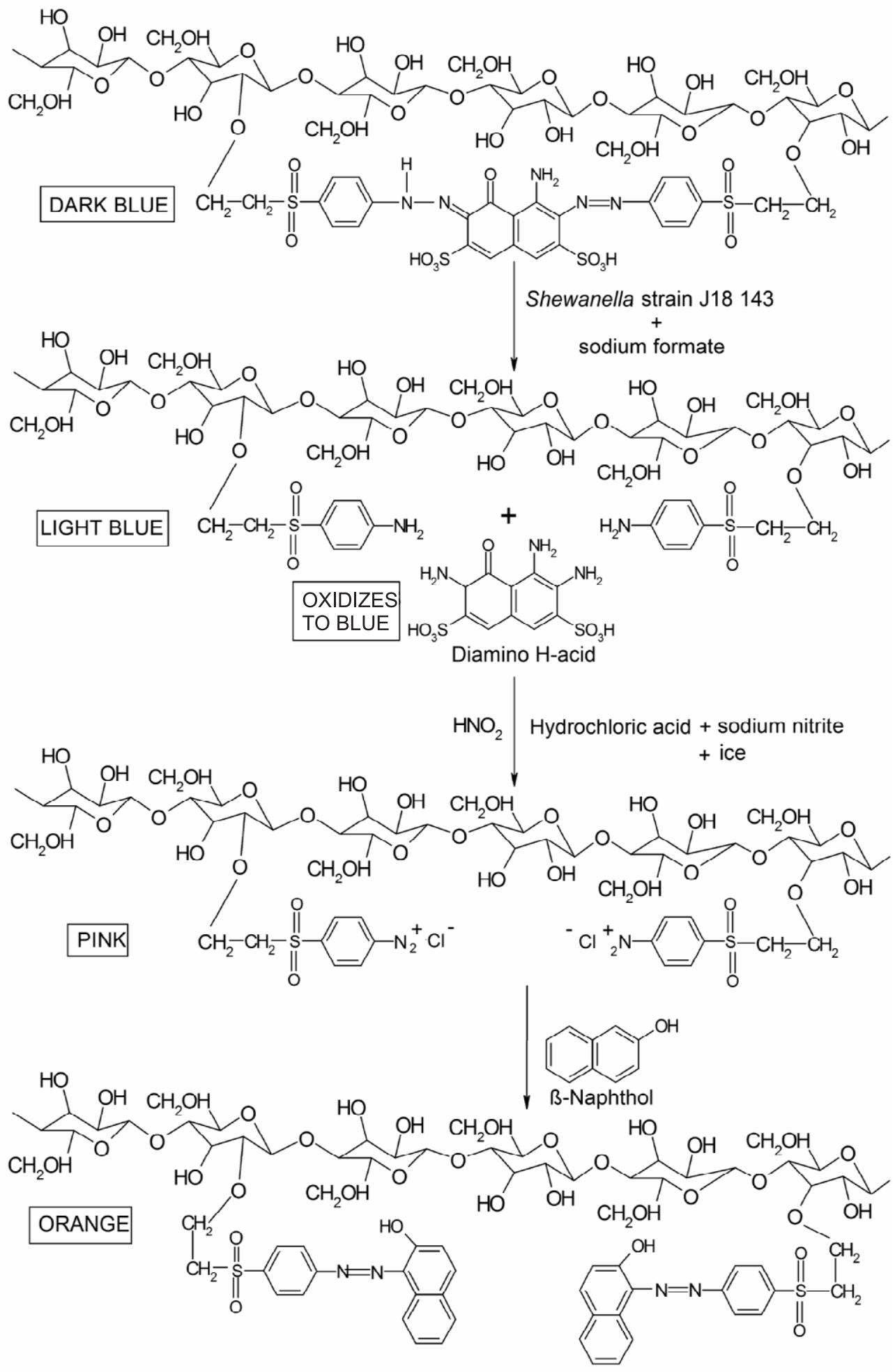

Figure 12 Suggested mechanism for the reduction of C.I. Reactive Black 5 on cotton fabric ( $1 \%$ omf) using resting cell suspensions of Shewanella strain J18 143. followed by diazotization of any available amines and coupling with $\beta$-naphthol. 
5 molecule was not particularly available for reaction. However, a significant color change occurred with the fabric sample that had been biologically reduced, confirming the presence of a substantial number of amine groups attached to the cotton fabric (Figure 11c).

The results of this simple qualitative test provided valuable supporting evidence for the concept that the azo/ketohydrazone bonds in the C.I. Reactive Black 5 molecule are reductively cleaved by the Shewanella strain J18 143 cells to leave amino groups, most probably para-base related, attached to the fabric. Also, the results in Figure 11 highlight that the amino groups on the cotton fabric are available for functionalization. This option could open up a whole new range of potential uses in the field of functionalized polymers.

From the results in Figure 11 and the series of color changes observed during the experiments, a suggested mechanism for the biological reduction of Reamzol Black B on cotton fabric, followed by diazotization and coupling, can be proposed (Figure 12). The formation of amines on the surface of the cotton fabric will certainly have implications for the potential re-use of the fabric, once the color has been removed. If the amines could be fully characterized, it may be possible to re-dye the fabric using diazotization and coupling to achieve the desired shade. Figure 11 represents an example of such a possibility.

\section{Reduction of C.I. Reactive Black 5 on Cotton Fabric Through a Dialysis Membrane Using Anaerobic Resting Cell Suspensions of Shewanella Strain J18 143}

Dyed cotton fabric was isolated inside a dialysis membrane to prevent contact with the cells. The objective was to ascertain whether or not the extracellular electron transfer mechanism employed by Shewanella strain J18 143 involves an endogenous shuttle to transfer electrons from the cell, through the membrane, to the azo/ketohydrazone bonds in the dye molecule on the cotton. This would be advantageous when considering the application of Shewanella strain J18 143 cells in an industrial bio-bleaching process as it would negate the need for direct contact of the biological component with the dyed fabric, eliminating problems associated with contamination and potential damage to the fibers. Certain strains of the Shewanella species have been found to secrete redox-active molecules for this purpose [20]. These redox-active molecules have recently been identified as flavin mononucleotide (FMN) and riboflavin [15]. In these experiments, the exogenous electron shuttle, AQDS, was added to some experiments to act as a positive control and also to provide a comparison between the reduction rates of the exogenous electron shuttle and the endogenous electron shuttle. Figure 13 shows the change in K/S values, at the $\lambda_{\max }$ for C.I. Reactive Black $5(597 \mathrm{~nm})$ for dyed cotton fabric, through a dialysis membrane, supplied with

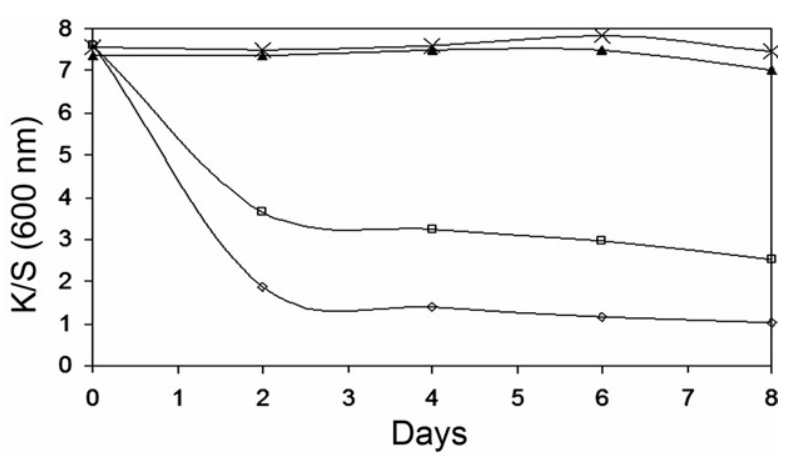

Figure 13 Reduction of C.I. Reactive Black 5 on cotton fabric through a dialysis membrane in phosphate-buffered saline and supplied with sodium formate at $30^{\circ} \mathrm{C}$. without cells $(X)$, without cells and with $\operatorname{AQDS}(\mathbf{A})$, with cells $(\square)$, and with cells and AQDS $(\diamond)$.

sodium formate at $\mathrm{pH} 7$ and $30^{\circ} \mathrm{C}$, without cell suspension and without AQDS, without cell suspension and with AQDS, with cell suspension and without AQDS and with cell suspension and with AQDS. The study was carried out over a period of 8 days.

There was no reduction of the dye on the fabric, through the dialysis membrane, in the absence of the Shewanella strain J18 143 cell suspension, either with or without the addition of the exogenous electron shuttle, AQDS. However, a significant amount of dye was reduced on the fabric, in the presence of the cells, through the dialysis membrane. Dye reduction occurred even without the addition of AQDS, which gives a strong indication that the Shewanella strain J18 143 cells were able to produce endogenous extracellular electron shuttles in keeping with other Shewanella strains, allowing them to reduce the azo dye through the dialysis membrane. The initial rates of microbial dye reduction through the dialysis membrane, without and with AQDS were $12.4 \mathrm{mg}$ dye g ${ }^{-1}$ (biomass) day ${ }^{-1}$ and $20.2 \mathrm{mg}$ dye $\mathrm{g}^{-1}$ (biomass) day ${ }^{-1}$, respectively. Therefore, the presence of an exogenous extracellular electron shuttle (AQDS), in conjunction with the endogenous extracellular electron shuttle (e.g. flavins), improved the efficiency of dye reduction.

When the dyed cotton fabric was placed into dialysis tubing to avoid bacterial contact, a measurable reduction of the dye occurred. This result provides strong evidence for the hypothesis that cell contact was not required for dye reduction using Shewanella strain J18 143. This is in agreement with Moser and Nealson [16], who found that direct cell to sulfur contact was not required for sulfur reduction by $S$. oneidensis MR-1, a close relative of Shewanella strain J18 143, because the cells were able to reduce particulate sulfur isolated behind a dialysis membrane. 


\section{Conclusions}

Cells of Shewanella strain J18 143 are able to reduce the azo chromophores present in C.I. Reactive Black 5 dye molecules, bonded on to cotton fabric. Preliminary studies have also shown that a process involving Shewanella strain J18 143 cells would be applicable to a range of other dyed fabrics including cotton dyed with C.I. Reactive Orange 16 and C.I. Direct Red 83:1, as well as nylon dyed with C.I. Acid Red 336 [21]. The uniform manner in which the color removal occurred suggests that, rather than reducing the dye via a mechanism involving direct physical contact, the cells create an effective reducing environment in which electrons are transferred to all the available electron acceptors in the dyed cotton fabric. Color removal from the dyed cotton fabric was affected by the concentration of cells used and the amount of dye present on the fabric.

An additional electron donor is not required for the reduction of C.I. Reactive Black 5 on cotton fabric using Shewanella strain J18 143 because the cotton itself appears to provide the electrons necessary for the microbial reduction. However, an increase in the reduction rate through the optimization of other process variables would necessitate the use of the physiological electron donor, such as sodium formate, to prevent the electron donor becoming a rate-limiting factor.

The addition of AQDS as an extracellular redox mediator considerably improved the rate of dye reduction over the initial 24-hour period. The nitrous acid test [14] confirmed that the reductive cleavage of azo bonds in dye molecules on cotton fabric by Shewanella strain J18 143 resulted in the formation of amino compounds that remained attached to the fabric. These amino compounds are available for functionalization. When the dyed cotton fabric was placed into dialysis tubing to avoid bacterial contact, a measurable reduction of the dye occurred. This suggests that Shewanella strain J18 143 cells are able to synthesize and excrete endogenous extracellular electron shuttles, eliminating the need for direct contact between the intracellular electron transport components and the extracellular terminal electron acceptors, offering a significant advantage for the application of these cells as biocatalysts in an industrial bio-bleaching process.

\section{Acknowledgements}

This research was supported by grants from the Engineering and Physical Sciences Research Council and Biotechnology and Biological Sciences Research Council (grant BBS/B/03718). We acknowledge Dystar UK Ltd for supplying the dyes and P. Broadbent for assistance with producing the dyed cotton fabric. We also thank P. Hill for his assistance with using the environmental scanning electron microscope.

\section{Literature Cited}

1. Pearce, C. I., Christie, R., Boothman, C., von Canstein, H., Guthrie, J. T., and Lloyd, J. R., Reactive Azo Dye Reduction by Shewanella Strain J18 143, Biotechnol. Bioeng., 95(4), 692703 (2006).

2. Tiedje, J. M., Shewanella - The Environmentally Versatile Genome, Nat. Biotechnol., 20(11), 1093-1094 (2002).

3. Heidelberg, J. F., Paulsen, I. T., Nelson, K. E., Gaidos, E. J., Nelson, W. C., Read, T. D., Eisen, J. A., Seshadri, R., Ward, N., Methe, B., Clayton, R. A., Meyer, T., Tsapin, A., Scott, J., Beanan, M., Brinkac, L., Daugherty, S., DeBoy, R. T., Dodson, R. J., Durkin, A. S., Haft, D. H., Kolonay, J. F., Madupu, R., Peterson, J. D., Umayam, L. A., White, O., Wolf, A. M., Vamathevan, J., Weidman, J., Impraim, M., Lee, K., Berry, K., Lee, C., Mueller, J., Khouri, H., Gill, J., Utterback, T. R., McDonald, L. A., Feldblyum, T. V., Smith, H. O., Venter, J. C., Nealson, K. H., and Fraser, C. M., Genome Sequence of the Dissimilatory Metal Ion-reducing Bacterium Shewanella oneidensis, Nat. Biotechnol., 20, 1118-1123 (2002).

4. Pearce, C. I., Lloyd, J. R., and Guthrie, J. T., The Removal of Colour from Textile Wastewater Using Whole Bacterial Cells: A Review, Dyes and Pigments, 58(3), 179-196 (2003).

5. Willmott, N. J., "The Use of Bacteria-Polymer Composites for the Removal of Colour from Reactive Dye Effluents", PhD Thesis, University of Leeds, 1997.

6. Kamilaki, A., "The Removal of Reactive Dyes from Textile Effluents - A Bioreactor Approach Employing Whole Bacterial Cells", PhD Thesis, University of Leeds, 2000.

7. Pearce, C. I., Guthrie, J. T., and Lloyd, J. R., Reduction of Pigment Dispersions by Shewanella Strain J18 143, Dyes and Pigments, 76, 696-705 (2008).

8. Kirby, N., Marchant, R., and McMullan, G., Decolourisation of Synthetic Textile Dyes by Phlebia tremellosa, FEMS Microbiol. Lett., 188, 93-96 (2000).

9. Ambrósio, S. T., and Campos-Takaki, G. M., Decolorization of Reactive Azo Dyes by Cunninghamella elegans UCP 542 Under Co-metabolic Conditions, Bioresour. Technol., 91(1), 69-75 (2004).

10. Belghith, H., Ellouz-Chaabouni, S., and Gargouri, A., Biostoning of Denims by Penicillium occitanis (Pol6) Cellulases, $J$. Biotechnol., 89, 257-262 (2001).

11. Rodríguez Couto, S., and Toca-Herrera, J. L., Lacasses in the Textile Industry, Biotechnol. Mol. Biol. Rev., 1(4), 117-122 (2006).

12. Amorim, A. M., Gasques, M. D. G., Andreaus, J., and Scharf, M., The Application of Catalase for the Elimination of Hydrogen Peroxide Residues after Bleaching of Cotton Fabrics, An. Acad. Bras. Cienc., 74(3), 433-436 (2002).

13. Hasan, F., Ali Shah, A., and Hameed, A., Industrial Applications of Microbial Lipases, Enzyme Microb. Technol., 39, 235251 (2006).

14. Green, A. G., "The Analysis of Dyestuffs and Their Identification in Dyed and Coloured Material, Lake-Pigments and Foodstuffs etc.", 3rd edn, Charles Griffin and Company Ltd, London, 1949.

15. von Canstein, H., Ogawa, J., Shimizu, S., and Lloyd, J. R., Secretion of Flavins by Shewanella Species and Their Role in Extracellular Electron Transfer, Appl. Environ. Microbiol., 74(3), 615-623 (2008). 
16. Moser, D. P., and Nealson, K. H., Growth of the Facultative Anaerobe Shewanella putrefaciens by Elemental Sulfur Reduction, Appl. Environ. Microbiol., 62(6), 2100-2105 (1996).

17. Smith, P. K., Krohn, R. I., Hermanson, G. T., Mallia, A. K., Gartner, F. H., Provenzano, M. D., Fujimoto, E. K., Goeke, N. M., Olson, B. J., and Klenk, D. C., Measurement of Protein Using Bicinchoninic Acid, Anal. Biochem., 150, 76-85 (1985).
18. Neidhardt, F. C., Ingraham, J. L., and Schaechter, M., "Physiology of the Bacterial Cell: A Molecular Approach", Sinauer Associates, Massachusetts, 1990.

19. Characklis, G., and Marshall, K. C., "Biofilms", Wiley, New York, 1990.

20. Newman, D. K., and Kolter, R., A Role for Excreted Quinones in Extracellular Electron Transfer, Nature, 405, 94-97 (2000).

21. Walker, C. L., "Reduction of Bonded Azo Dyes", MEnt, University of Manchester, 2007. 